\title{
Tingkat Pengetahuan Publik (Public Knowledge) Terhadap Penyakit Hewan Menular Strategis Rabies Dalam Upaya Mendukung Status Lombok Bebas Rabies
}

\author{
Made Sriasih*, Sulaiman N Depamede, Wayan Wariata, Muhamad Ali, Anwar Rosyidi \\ Laboratorium Mikrobiologi dan Bioteknologi Fakultas Peternakan Universitas Mataram \\ Jalan Majapahit No. 62 Mataram 83125 NTB
}

\begin{abstract}
Article history
Received: 07-10-2020

Revised: 20-10-2020

Accepted: 24-10-2020

*Corresponding Author:

Made Sriasih,

Peternakan Universitas

Mataram, Nusa Tenggara

Barat, Indonesia
\end{abstract}

Email:

madesriasihphd@unram.ac.id

\begin{abstract}
Rabies is one of strategic infectious animal diseases that attacks the central nervous system. Rabies is very widespread and is found in nearly 150 countries and regions on all continents, except Antarctica. Although West Nusa Tenggara is one of the nine provinces in Indonesia that is free of rabies, the number of dog bite victims reported on the island of Sumbawa with 32 samples of rabiescarrying animal brains identified as positive in early 2019 indicates the need to increase awareness of rabies transmission to Lombok Island. Increasing public knowledge which includes parents and students at primary school, elementary school and high school about rabies through surveys, counseling and demonstration is one of the efforts to prevent and control rabies. The results showed that the extension activities were able to increase participants' knowledge. High school students had the best level of knowledge $(97.5 \% \pm 2.08)$ when compared to the elementary school participants $(93 \% \pm 3.56)$ and elderly respondents $(88.75 \% \pm$ 4.79) of all indicators of knowledge about rabies. The combination of extension activities with hands-on practice has had a positive effect on increasing public knowledge about rabies.
\end{abstract}

Keywords: Extension; Knowledge; Lombok, Rabies

Abtrak: Rabies merupakan salah satu jenis penyakit hewan menular strategis (PHMS) yang menyerang susunan syaraf pusat. Penyebaran penyakit rabies sangat luas dan hampir ditemukan di 150 negara dan wilayah di semua benua, kecuali Antartika. Meskipun Nusa Tenggara Barat termasuk dalam salah satu dari sembilan propinsi di Indonesia yang bebas rabies, banyaknya korban gigitan anjing yag dilaporkan di pulau Sumbawa dengan 32 sampel otak hewan pembawa rabies terindentifikasi positif di awal tahun 2019 mengisyaratkan perlunya meningkatkan kewaspadaan terhadap penularan rabies ke pulau Lombok. Peningkatan pengetahuan publik yang meliputi orang tua, siswa dan siswi Sekolah Dasar (SD), Sekolah Menengah Pertama (SMP) dan Sekolah Menengah Atas (SMA) tentang rabies melalui kegiatan survei, penyuluhan dan demonstrasi merupakan salah satu usaha usaha pencegahan dan pengendalian penyakit. Hasil kegiatan menunjukkan bahwa penyuluhan yang diberikan mampu meningkatkan pengetahuan partisipan. Siswa/i SMA memiliki tingkat pengetahuan yang paling baik $(97.5 \% \pm 2.08)$ jika dibandingkan dengan kelompok partisipan SMP $(93 \% \pm 3.56)$ dan orang tua $(88.75 \% \pm 4.79)$ dari semua indikator pengetahuan tentang rabies. Kombinasi kegiatan penyuluhan dengan praktik langsung memberikan efek yang positif terhadap peningkatan pengetahuan publik tentang rabies.

Kata Kunci: Penyuluhan; Pengetahuan; Lombok; Rabies 


\section{PENDAHULUAN}

Rabies merupakan salah satu jenis penyakit hewan menular strategis yang menyerang susunan syaraf pusat. Penyakit ini disebabkan oleh virus RNA (ribonucleic acid) dari genus Lyssavirus famili Rhabdoviridae. Virus rabies berbentuk seperti peluru yang bersifat neurotropis, menular dan sangat ganas serta dapat menyerang semua hewan berdarah panas dan manusia.

Penyebaran penyakit rabies sangat luas dan hampir ditemukan di 150 negara dan wilayah di semua benua, kecuali Antartika. Namun 95\% kasus rabies dilaporkan dari benua Asia dan Afrika (Pusat Data dan Informasi Kementerian Kesehatan RI, 2017). Kejadian rabies pada hewan maupun manusia hampir selalu diakhiri dengan kematian (case fatality rate 100\%). Berdasarkan data World Health Organization (WHO) diperkirakan 55.000 orang di dunia meninggal akibat rabies setiap tahunnya (Pusat Data dan Informasi Kementerian Kesehatan RI, 2017) sehingga menimbulkan rasa takut dan keresahan bagi masyarakat.

Rabies pertama kali dilaporkan oleh Esser di Indonesia pada tahun 1884 pada seekor kuda di Jawa Barat. Pada tahun 1890 kasus rabies dilaporkan terjadi pada anjing di Tangerang. Kasus rabies pada manusia dilaporkan oleh Van de Haan tahun 1894 pada seorang anak di desa Paliamanan, Cirebon. Sampai tahun 2017, rabies tersebar di 24 propinsi di Indonesia sedangkan 9 propinsi bebas rabies di antaranya 5 propinsi bebas historis (Papua, Papua Barat, Bangka Belitung, Kepulauan Riau dan Nusa Tenggara Barat), dan 4 propinsi dibebaskan (Jawa Tengah, Yogyakarta, Jawa Timur dan Daerah Khusus Ibukota (DKI) (Pusat Data dan Informasi Kementerian Kesehatan RI, 2017).

Sebagian besar kasus rabies (98\%) pada manusia berdasarkan data World Health Organization (WHO) disebabkan oleh gigitan hewan pembawa rabies (HPR) terutama anjing (WHO, 2013) sedangkan sisanya oleh hewan lain seperti kucing dan monyet. Virus Lyssa yang terdapat pada air liur HPR akan menginfeksi sistem saraf tepi dan menuju ke otak setelah manusia tergigit oleh HPR. Gejala klinis yang timbul pada manusia setelah virus menyerang otak adalah encephalomyelitis dan hidrofobia yang merupakan gejala khas rabies (Novita, 2019).

Kasus rabies di Nusa Tenggara Barat (NTB) pertama kali dilaporkan pada anjing di Dompu di awal tahun 2019. Sampai akhir Februari 2019, sebanyak 825 korban gigitan anjing dilaporkan di NTB. Dari jumlah tersebut, 32 sampel otak HPR terindentifikasi positif rabies dan 8 warga Dompu diantaranya meninggal dunia. Kondisi ini menyebabkan pemerintah daerah kabupaten Dompu dan Sumbawa menetapkan status kejadian luar biasa (KLB) rabies khusus untuk Dompu dan Sumbawa.

Pulau Lombok saat ini masih bebas dari rabies namun peningkatan kewaspadaan terhadap penularan rabies harus tetap dilakukan seperti pengawasan lalulintas HPR yang ketat di pelabuhanpelabuhan yang menjadi pintu masuk utama ke pulau Lombok. Selain pegawasan, Dinas Peternakan dan Kesehatan Hewan juga melakukan vaksinasi terhadap HPR dan sosialisasi.

Nugroho dkk. (2013) menyatakan bahwa banyak faktor dan usaha yang dapat dilakukan untuk mencegah rabies. Namun salah satu faktor kunci pencegahan rabies pada manusia dan hewan adalah kolaborasi antara sektor kesehatan masyarakan dan kesehatan hewan untuk meningkatkan pengetahuan dan kesadaran masyarakat mengenai penyakit rabies melalui penyuluhan mulai dari lingkungan masyarakat kecil seperti kelurahan sampai pada tingkat desa maupun wilayah yang lebih luas. Belajar dari kejadian rabies di Bali, peningkatan pengetahuan masyarakat akan penyakit baru yang muncul disuatu daerah berkorelasi positif dengan dukungan masyarakat dalam usaha pencegahan dan pengendalian penyakit (Batan dan Suatha, 2013). 


\section{METODE}

Peningkatan pengetahuan masyarakat/publik yang meliputi orang tua, siswa dan siswi Sekolah Dasar (SD), Sekolah Menengah Pertama (SMP) dan Sekolah Menengah Atas (SMA) tentang rabies, upaya pencegahan dan pengendaliannya dilakukan dengan mengadakan survei melalui pengisian kuisinoner, penyuluhan dan demonstrasi. Total partisipan dalam kegiatan ini adalah 155 orang yang terdiri dari 35 orang siswa SD (SDN 2 Montong Are Timur, Kediri, Lombok Barat), 40 orang siswa SMP (SMPN 5 Mataram, Kota Mataram), 40 orang siswa SMA (SMAN 1 Gunung Sari, Lombok Barat) dan 40 orang peserta kelompok orang tua (ibu/bapak) dari desa Montong Are, Kediri, Lombok Barat. Rincian kegiatan adalah sebagai berikut:

a. Survei atau pendataan tingkat pengetahuan masyarakat (orang tua, siswa dan siswi SD, SMP dan SMA) tentang rabies. Kuisioner diberikan saat kunjungan ke masyarakat atau partisipan, dan partisipan khususnya orang tua, siswa/i SMP dan SMA menjawab semua pertanyaan/informasi dalam kuisioner sehingga didapatkan data pengetahuan tentang rabies. Data tingkat pengetahuan dikelompokkan kedalam 3 kategori: kurang (di bawah 50\%); sedang (51-80\%); baik (di atas 80\%).

b. Penyuluhan. Penyuluhan dalam bentuk kegiatan tatap muka dengan masyarakat (orang tua, siswa dan siswi SD, SMP dan SMA) disertai dengan alat peraga dan pemutaran video tentang rabies. Dari kegiatan penyuluhan ini diharapkan partisipan mendapatkan pengetahuan tentang rabies.

Demonstrasi. Kegiatan demonstrasi dilakukan oleh Tim pengabdian laboratorium Mikrobiologi dan Bioteknologi Fakultas Peternakan Unram bersama-sama dengan tim Dinas Peternakan dan Keshatan Hewan Prop. NTB. Partisipan diberikan praktek langsung cara mengatasi kasus gigitan anjing pembawa rabies. Dari kegiatan demonstrasi ini, partisipan dapat melakukan pertolongan pertama dengan benar dan baik jika ada kasus gigitan anjing pembawa rabies.

\section{HASIL DAN PEMBAHASAN}

Salah satu usaha yang dapat dilakukan untuk mendukung program zero rabies di pulau Lombok adalah meningkatkan pengetahuan publik/masyarakat terhadap bahaya rabies melalui kegiatan survei, penyuluhan dan demonstrasi. Survei dilakukan untuk mendapatkan data tentang tingkat pengetahuan partisipan terhadap penyakit rabies. Partisipan dalam kegiatan ini dibagi dalam beberapa kelompok seperti disajikan pada Tabel 1.

Kuisioner tertulis hanya diberikan pada orang tua, siswa/i SMP dan SMA (Gambar 1), sedangkan untuk siswa sekolah dasar hanya dilakukan penggalian informasi secara informal dengan pertanyaan-pertanyaan sederhana secara lisan.

Tabel 1. Partisipan kegiatan pengabdian tentang rabies

\begin{tabular}{lllll}
\hline & Partisipan & Tempat & Lokasi & Jumlah \\
\hline 1. & Orang tua (Ibu/Bapak) & Balai Desa Montong Are & Kediri & 35 orang \\
2. & Siswa/i SD & SDN 2 Montong Are Timur & Kediri & 40 orang \\
3. & Siswa/i SMP & SMPN 5 Mataram & Babakan & 40 orang \\
4. & Siswa/i SMA & SMAN 1 Gunungsari & Gunungsari & 40 orang \\
\hline
\end{tabular}




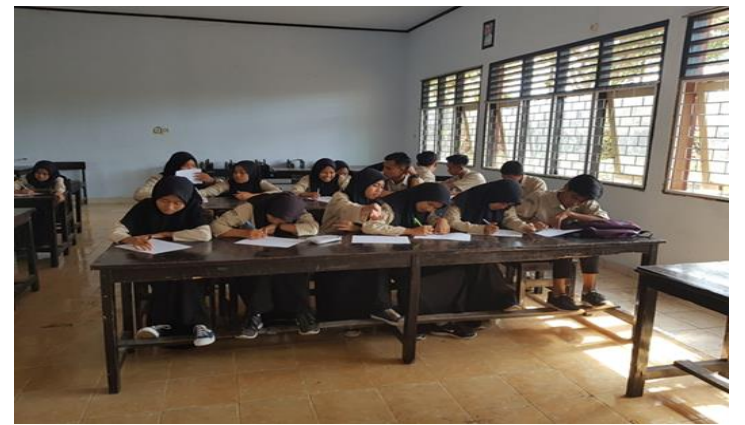

Gambar 1. Proses pengisian kuisioner di SMAN 1 Gunungsari sebagai salah satu mitra partisipan

Data tentang tingkat pengetahuan masyarakat yang didapatkan melalui pengisian kuisioner sebelum kegiatan penyuluhan disajikan pada Tabel 2.

Tabel 2. Tingkat pengetahuan masyarakat tentang rabies sebelum kegiatan penyuluhan

\begin{tabular}{|c|c|c|c|c|}
\hline \multirow{3}{*}{ Indikator pengetahuan } & \multicolumn{4}{|c|}{ Tingkat Pengetahuan Kelompok Partisipan } \\
\hline & \multirow[t]{2}{*}{ SD } & SMP & \multirow[t]{2}{*}{$\mathbf{S M}$} & Orang \\
\hline & & & & tua \\
\hline Penyebab rabies & N/A & $80 \%$ & $87.5 \%$ & $71.42 \%$ \\
\hline Hewan penular & N/A & $67.5 \%$ & $75 \%$ & $57.14 \%$ \\
\hline Pencegahan & N/A & $90 \%$ & $90 \%$ & $68.57 \%$ \\
\hline Tindakan & N/A & $62.5 \%$ & $72.5 \%$ & $62.85 \%$ \\
\hline Rerata \pm SD & N/A & $75 \% \pm 12.41$ & $81.25 \% \pm 8.78$ & $64.99 \% \pm 6.33$ \\
\hline
\end{tabular}

Data pada Tabel 2 menunjukkan bahwa dari semua indikator pengetahuan yang diinginkan, siswa/i SMA memiliki tingkat pengetahuan yang paling baik jika dibandingkan dengan kelompok partisipan SMP dan orang tua. Pengetahuan kelompok partisipan SMP dan orang tua tentang penyebab rabies termasuk dalam kategori sedang (80\% dan 71.42\%) sedangkan siswa/i SMA termasuk dalam kategori baik $(87.5 \%)$. Pengetahuan tentang hewan pembawa rabies atau penular disemua kelompok partisipan termasuk dalam kategori sedang. Secara umum partisipan memberikan jawaban bahwa hanya anjing yang merupakan hewan pembawa rabies. Tansil (2104) menyatakan bahwa seluruh hewan berdarah panas dapat terkena rabies, tapi belum tentu bisa menularkannya. Hewan berdarah panas adalah hewan yang dapat menjaga suhu tubuhnya dalam kondisi konstan, meskipun cuaca dingin atau panas, dan yang termasuk dalam golongan tersebut adalah jenis burung (aves) dan hewan menyusui (mamalia).

Hewan yang dapat menularkan rabies atau disebut sumber infeksi hewan penular rabies, antara lain adalah: anjing, kucing, kera, kelelawar, rakun dan musang. Sedangkan hewan seperti sapi, lembu atau kelinci bisa tertular tapi tidak menularkan ke manusia, atau disebut dead end. Berdasarkan data WHO (WHO, 2013) hampir 98 persen kasus rabies terjadi akibat gigitan anjing.

Siswa/i SMP dan SMA memiliki tingkat pengetahuan baik (>80\%) tentang cara untuk mencegah terjadinya rabies. Namun demikian, semua kelompok partisipan memiliki tingkat pengetahuan sedang tentang tindakan yang harus dilakukan jika terjadi gigitan hewan terduga rabies. Tindakan yang paling tepat untuk dilakukan adalah mencuci luka menggunakan air mengalir dengan sabun atau deterjen selama 10-15 menit. Tindakan ini bertujuan untuk menghambat penetrasi virus kedalam jaringan. Setelah bersih, luka gigtan harus diberikan antiseptik. 
Setelah kegiatan penyuluhan dan demonstrasi tingkat pengetahuan publik/masyarakat mengalami peningkatan (Tabel 3).

Tabel 3. Tingkat pengetahuan masyarakat tentang rabies setelah kegiatan penyuluhan

\begin{tabular}{lcccc}
\hline \multirow{2}{*}{ Indikator pengetahuan } & \multicolumn{4}{c}{ Tingkat Pengetahuan Kelompok Partisipan } \\
\cline { 2 - 5 } & SD & \multicolumn{1}{c}{ SMP } & SMA & Orang tua \\
\hline Penyebab rabies & N/A & $90 \%$ & $98 \%$ & $85 \%$ \\
Hewan penular & N/A & $97 \%$ & $97 \%$ & $90 \%$ \\
Pencegahan & N/A & $95 \%$ & $95 \%$ & $95 \%$ \\
Tindakan & N/A & $90 \%$ & $100 \%$ & $85 \%$ \\
Rerata \pm SD & N/A & $93 \% \pm 3.56$ & $97.5 \% \pm 2.08$ & $88.75 \% \pm 4.79$ \\
\hline
\end{tabular}

N/A: data tidak tersedia

Data pada Tabel 3 menunjukkan bahwa tingkat pengetahuan partisipan disemua indikator termasuk kedalam kategori baik (lebih dari 80\%) setelah kegiatan pengabdian pada masyarakat. Hal ini mengindikasikan bahwa masyarakat memahami dengan baik materi penyuluhan yang diberikan. Kombinasi kegiatan penyuluhan dengan praktek langsung memberikan efek yang positif terhadap peningkatan pengetahuan publik tentang rabies.

\section{KESIMPULAN DAN SARAN}

\section{Kesimpulan}

Siswa/i SMA memiliki tingkat pengetahuan yang paling baik jika dibandingkan dengan kelompok partisipan SMP dan orang tua dari semua indikator pengetahuan tentang rabies. Kombinasi kegiatan penyuluhan dengan praktik langsung memberikan efek yang positif terhadap peningkatan pengetahuan publik tentang rabies.

\section{Saran}

Diperlukan promosi kesehatan yang berkelanjutan di masyarakat untuk meningkatkan kewaspadaan dan kepedulian masyarakat terhadap bahaya rabies di lingkungan sekitar sehingga status bebas (zero) rabies di pulau Lombok dapat terus dipertahankan.

\section{Ucapan Terima Kasih}

Penulis mengucapkan terima kasih kepada Universitas Mataram yang telah mendanai kegiatan pengabdian ini dengan surat perjanjian nomor: 2196/UN18/LPPM/2019 tanggal 02 Mei 2019. Penulis juga mengucapkan terima kasih kepada pihak desa dan sekolah serta semua partisipan yang terlibat dalam kegiatan pengabdian ini.

\section{DAFTAR PUSTAKA}

Batan, I. W. dan Suatha, I. K. 2016. Faktor-faktor yang mendorong kejadian rabies pada anjing di desa-desa di Bali. Jurnal Veteriner, 17(2): 274-279.

Nugroho, D. K., Pudjiatmoko, I. K. Diarmitha, Tum, S. and Schoonman, L. 2013. Analisa data surveilans rabies (2008-2011) di propinsi Bali, Indonesia. Outbreak, Surveillance and Investigation Reports, 6(2): 8-12. 
Pusat Data dan Informasi Kementerian Kesehatan RI. 2017. Situasi rabies di Indonesia. Kementerian Kesehatan RI.

Novita, R. 2019. Peran Fasilitas Pelayanan Kesehatan dalam Menghadapi Tantangan Rabies di Indonesia. Jurnal Penelitian dan Pengembangan Pelayanan Kesehatan, 3(2): 94-105.

Tansil, K. 2014. Penyakit rabies dan penatalaksanaannya. E-Journal WIDYA Kesehatan Dan Lingkungan, 1(1): 61-67.

WHO. 2013. WHO Expert Consultation on Rabies. Second report. WHO technical report series 982. World Health Organization, Geneva, Switzerland. 